\title{
Engineering substantially prolonged human lifespans: biotechnological enhancement and ethics
}

Peter Derkx

\section{Introduction}

Substantial extension of the human lifespan has recently become a subject of lively debate. One reason for this is the completion in 2001 of the Human Genome Project and the experimental avenues for biogerontological research it has opened. Another is recent theoretical progress in biogerontology. In the 1990s more and more biogerontologists began to agree on the evolutionary cause of senescence: it results from a trade-off between the investment of resources in reproduction on the one hand and in maintenance and repair of the body on the other.This represents a powerful simplification of the theoretical underpinnings of biogerontological research, necessary to make anti-ageing technology a plausible idea (Hayflick, 1994; Holliday, 1995, 2006; Austad, 1997; Kirkwood, 2005).

But the character of modern culture is at least as important an explanation of the current debate on life-extension intervention. Three existential factors playing a role here are fear of death (fear of no longer existing), fear of the suffering involved in the process of dying, and the sometimes obsessive desire to preserve good health in order to pursue life projects and goals (Turner, 2004).The historical background of this motivational pattern is

... the decline since the Renaissance of faith in supernatural salvation from death; concern with the worth of individual identity and experience shifted from an otherworldly realm to the 'here and now', with intensification of earthly expectations. (Gruman, quoted in Post, 2004a: 82)

A specific occasion for strong interest in 'anti-ageing medicine' is the ageism many people seem to encounter in conventional medicine:

Anti-aging practitioners largely rebel against the age norms accepted by more mainstream medicine. In other words, for these practitioners, there is no 'normal' that should be accepted for a man of 72 years 
when, instead, we can target his care toward the 'norms' of a 30 year old man. (Mykytyn, 2006: 282, emphasis in original)

Interest in substantial life extension is large, therefore, and in a volume on ageing and values such a project might easily be assumed to be worthy of support: if later life is good, more of it would be better.

But would this really be a good thing? Experience with other revolutionary technologies is that, once they exist, they can no longer be stopped. Too much has been invested in them: once research has produced an effective technology catering to all-too-human desires, there is seldom a return path. We had better investigate the ethical aspects of considerable human lifespan extension now, before this extension has become genuinely practicable, or before large sums of money have been spent on it. We shall see, first, that these apparently technical, biomedical questions cannot be discussed without considering ethics and values, and, second, that this investigation inevitably demands that we try to conceptualise something of what ageing itself and being human is about.

\section{Substantial extension of human lifespan: what are we talking about?}

Before embarking on an ethical discussion it has to be clear what we mean by 'substantial extension of human lifespan'. We can distinguish between four possible outcomes of a biotechnological enhancement of the human lifespan.Varying on work by Harry Moody (1995), Eric Juengst and others (Juengst et al, 2003: 248 ), we can term these extended morbidity, compressed morbidity, decelerated senescence and arrested senescence.

Extended morbidity means that the average human life becomes longer because the period of (co)morbidity at the end is lengthened.Through good hygiene, nutrition, education, housing, medical care, welfare arrangements and social services, older people with one or more chronic diseases stay alive longer. This means that average life expectancy increases, but this need not be an increase in human flourishing and cause for joy. Extended or prolonged morbidity does not entail an increase in maximum human life expectancy. A typical time structure for a human life with extended morbidity could be: growing up from 0 to 20 , adult health span 20 to 55 , period of growing morbidity up to 95 as the average age at death and with an unchanged maximum of around 120. Extended morbidity is a scenario some scientists (Baltes, 2003: 17) fear as the most likely one, with Alzheimer's disease as one of the main threats. ${ }^{1}$ Since nobody wishes it to become reality, we shall not discuss the ethical desirability of this type of life extension here.

Compressed morbidity is a scenario in which the onset of serious age-associated maladies is delayed as long as possible and thus these are compressed into a shorter period. The maximum human lifespan of around 120 is accepted as fixed. The focus of compressed morbidity is that the average human health span is extended to a much longer period from 20 up to 'the ideal average life span, approximately 
85 years' (Fries, 1980:130) followed by a relatively short period of decline before death, a period of one or two years at the most.

The feasibility of compressing morbidity for the life stage between 55 and 85 was first argued for by James Fries in 1980 and it has been embraced by many - for example, the biogerontologist Robert Arking (2004: 179). Not long ago three officials of the World Health Organization (WHO) wrote that Fries's tenets and vision 'now lie at the heart of today's approach to NCDs [noncommunicable diseases], ageing and health with its focus on the life course, health promotion, and "active ageing" [use it or lose it]' (Kalache et al, 2002: 243). Because its original assumption is that the maximum human lifespan is biologically predetermined at around 120 and that death at an average age of 85 is 'natural' and even 'ideal', compression of morbidity is not a form of substantial life extension. It must be noted, however, that many gerontologists hold that compression of morbidity is actually impossible. They think it highly unlikely that we will be able to increase health span without simultaneously increasing lifespan and the period of morbidity at the end. ${ }^{2}$ Compression of morbidity then turns out to be practically the same as delayed or decelerated senescence.

Decelerated senescence is an outcome in which processes of biological ageing are slowed, resulting in higher average life expectancy and probably higher maximum life expectancy. Decelerated senescence means that the period of good health in a human life is extended (as in the scenario of compressed morbidity), but the period of morbidity remains the same or is lengthened as well (as in extended morbidity). The average pattern of a human life in this case could be: growing up 0-20, adult health span 20-90 and period of decline after that with death at an age of 112. Maximum life expectancy at birth might be 140 years.

Richard Miller is a respected biogerontologist who considers that such a retarded or decelerated senescence is the most likely development:

Nature can slow down aging, and so, it turns out, can we. There are so far two approaches that work for sure: diminished total caloric intake and changes in genes that regulate the rate of early-life growth. (Miller, 2004: 233)

A recent and clear manifestation of the idea of decelerated senescence can be found in an article by Jay Olshansky and others, including Miller (Olshansky et al, 2006). They can be regarded as representatives of a growing chorus of scientists terming themselves 'moderate', 'modest' and 'realistic'. They firmly believe that an investment now of three billion US dollars annually will make it possible to decelerate ageing and the onset of ageing-related diseases and disorders among the baby boom cohorts by seven years:

People who reach the age of 50 in the future would have the health profile and disease risk of today's 43-year-old; those aged 60 would resemble current 53-year-olds, and so on. Equally important, once 
achieved, this seven-year delay would yield equal health and longevity benefits for all subsequent generations, much the same way children born in most nations today benefit from the discovery and development of immunizations. (Olshansky et al, 2006: 32)

Arrested senescence refers to relatively complete control of the biological processes of senescence. In this scenario, ageing in the sense of senescence or physical and mental deterioration does not occur any more, or the human organism is cared for very well (maintenance) and what senescence occurs is periodically repaired by a rejuvenation cure. For decades or centuries the chance to die does not increase with age any more, but stays rather constant. People still die, but they no longer die from the slow accumulation of damage and chronic deterioration. Instead they die from accident, murder or war. In this scenario people can become very old. Average life expectancies of 150,500 or even 5,000 years are thought to be possible.

Discussing the engineering of arrested senescence may evoke images of quackery, pseudoscience or science fiction. But a number of important organisations that promote anti-ageing and eventually arrested senescence exist: the American Academy of Anti-Aging Medicine (A4M), the Gerontology Research Group, the Longevity Meme, the Immortality Institute, the Maximum Life Foundation, the Life Extension Foundation and the World Transhumanist Association. Influential individuals promoting arrested senescence include Deepak Chopra, Ronald Klatz, Michael Brickey, Jean Carper, Gary Null, Walter Pierpaoli, Johannes Huber, Joao Pedro de Magalhaes, Max More, Nick Bostrom, James Hughes, Robert A. Freitas, $\mathrm{Jr}$ and Ray Kurzweil.

One of the strongest defenders of the scientific credibility of Strategies for Engineering Negligible Senescence (SENS) is the English biogerontologist Aubrey de Grey. He not only vehemently argues that humanity needs to set aside massive sums of money for a war on ageing, he also has embarked, together with relevant specialists, on detailing biotechnological measures we could use to beat the 'seven deadly things' 3 that accumulate with age as side-effects of metabolism (de Grey et al, 2002; de Grey, 2003, 2005). He expects that, between 2025 and 2040 , we will be able to fix these problems (to a large extent through genetic interventions and stem cell therapies) and that, around 2050, 'robust human rejuvenation' will be generally accessible. He realises that the first fixes will be imperfect, but they will give us time to develop better repair methods. According to de Grey, cancer is the hardest problem to solve, but he thinks it possible. Highly respected biogerontologists have attacked de Grey's ideas forcefully (Warner et al, 2005; Estep et al, 2006). It is important to note, however, that differences of opinion are mainly political, ethical and related to funding and estimates about the speed of future developments, and not about the possibility of substantial life-extension in itself.

We should note that the (US) President's Council on Bioethics has taken 'the possibility of extended youth and substantially prolonged lives' very seriously. In 
its 2003 report Beyond therapy (President's Council on Bioethics, 2003: 159-204) the Council warns against substantial life extension as a threat to the meaning of human lives.

\section{Life extension and ethics}

To offer some insight into the ethical aspect of life extension, I shall try to summarise the major ethical arguments for and against effective substantial extension of human lifespan, though intricate examination of each will not be possible. By substantial extension I mean decelerated senescence and arrested senescence as outlined above. Decelerated senescence is much more probable as the scenario for decades to come, but arrested senescence is certainly interesting and cannot be completely ruled out for the long run. From an ethical point of view, arrested senescence is significant. It forces us to think in new ways about what we consider most important in our lives and societies. This is significant even if arrested senescence itself turns out to be impossible.

Interpreting and adding to the framework by Stephen Post (2004b), I have organised the arguments in the following categories: autonomy, beneficence (including non-maleficence), distributive justice and meaning of life.

\section{Autonomy}

It is true that the principle or value of autonomy does not figure prominently in the ethical debate about life extension. Moreover, it is possible to regard autonomy or freedom not as an overriding principle but as one of the good things we value - discussing it under the category of beneficence. However, various kinds of consent and refusal are crucial in traditional biomedical ethics (Beauchamp and Childress, 2001), so it would seem anomalous not to approach it explicitly; besides, 'autonomy' is often referred to as a fundamental value in liberal democracies.

First of all, substantial extension of lifespan in the sense of decelerated or arrested ageing at this moment is (still) very much a collective matter. Decisions to try to extend human life substantially remain for the time being political or corporate decisions, for instance about priorities in medical research.Thus, taking autonomy seriously comes down to taking liberal democracy and citizenship seriously. Of course, there is debate about the best way to shape democracy in a highly multicultural, globalised and technological era (Benhabib, 1996; Habermas, 1998; Carens, 2000; Korten, 2000; Marres, 2005). The democracy debate is not uniquely concerned with matters of lifespan extension, but is highly relevant for how political decisions on life extension can best be made. How will it be possible, for example, to prevent social wrongs and injustice and at the same time respect individual reproductive liberty? Will future wealthy parents have the right to give their children genetically engineered substantially extended life expectancies that will be inheritable? Should the state be allowed to intervene in reproductive decisions in order to prevent injustice (Holm, 2004)? 


\section{Valuing older people}

Decisions about priorities in medical and biotechnological research will have impacts on future generations. Inevitably we must act paternalistically towards future generations; we cannot consult them. We can only try to judge imaginatively what will be good for them and not harm their interests. In some cases we can take precautionary measures, making it easier for people coming after us to reverse our decisions. This implies that we should be cautious with lifespan extension involving germline, hereditary genetic engineering. We must be conscientious in our judgements about what is good for future people. Perhaps engineering substantial life extension gives people a real choice they lack now; perhaps this is no problem at all, because people with extended lifespans could always decide for themselves and opt for suicide (Horrobin, 2005: 19). But would it not be problematic to create a society in which more and more people required this extraordinary exit strategy?

\section{Beneficence}

If society opts to allow itself and individuals the opportunity to make autonomous decisions about life extension, why should they choose or not choose much longer lives? An important aspect of the answer concerns the positive or negative effects that may reasonably be expected of the decision. Beneficence concerns the moral duty to contribute to the experience of things human beings value, including the duty to prevent harm - that is, the experience of things we value negatively. Now, what this means depends on what we ultimately value positively and negatively. Ultimate positive values that are often mentioned are preservation of (the quality of) life; enjoyment, pleasure, happiness, fulfilment or welfare; human company, friendship or community; self-respect and being respected by others; achievement despite obstacles; self-realisation or authenticity; creation and contemplation of beautiful things; knowledge; freedom, autonomy, independence or power; a healthy mind in a healthy body. Things that are valued negatively are the lack or loss of these things and pain and suffering.

The preservation and continuation of life is often mentioned first, but on closer inspection it is not life itself we ultimately want, but a certain quality of life characterised by a healthy body and an active mind endowed with memory and not overcome with pain (Brandt, 1959: 342; see also Horrobin, 2006). Christine Overall holds that the main argument in favour of life extension is not that life in itself is valuable, but 'that a longer life is the prerequisite for almost everything else that one might want' (Overall, 2004: 287). Because of the many possible things people might judge to be ultimate values, and because in a democracy we want to let people decide for themselves about this as much as possible, Overall's argument looks strong, because it is so general. But much longer life comes at a cost. Jeanne Calment, who died when she was 122 , stood at the graves of her husband, all her friends, her only daughter and even the grave of her only grandchild (Baars, 2006: 199). The vulnerability of human beings is not simply physical. It also has a crucial social dimension. Living very long might be attractive only if the people 
around you also live as long. Moreover, life extension also comes at a cost literally. Money spent on research into fundamental processes of biological ageing cannot be spent on asthma research or on education or art subsidies. And a society with a growing number of older and really old people will need much reorganisation. Costs and benefits (negative and positive effects) of life extension and longevity must be weighed against each other. Because it is not life in itself that we want, there might be things that are more important than longer life.

The quasi-neutral aspect of longevity - everybody can decide for themselves what to do with a longer life - makes it fit nicely into a liberal democracy and an individualistic society. But longer lives can also cause problems for what we think valuable. During the last decade we have seen many discussions about the 'greying' of society and the problems this will cause. This chapter can only deal with examples chosen to illustrate the nature and variety of problems involved.

The danger of an overpopulated world and the problems it entails has often been offered as an objection to substantial life extension. Population growth or reduction is not just the result of the death rate; the birth rate is at least as important a factor (Dykstra, 2002: 8). In general, birth rates tend to fall as life expectancy increases. Reproductive decision making governing fertility and parental investment might be driven by a human psychology designed by natural selection to maximise material wealth, not just the largest number of surviving and reproducing children (Borgerhoff Mulder, 1998; see also Hrdy, 1999). Many other, highly unpredictable factors are in play. To mention just one:

... human vulnerability [might increase] due to new infectious diseases or antibiotic resistant strains of bacteria ... Disease may well continue to be an effective leveller, improving its technology as we improve ours. (Harris, 2003: 75)

However, if substantial life extension is achieved and the death rate drops dramatically, would the decline in birth rate keep pace? Or would governments have to resort to drastic measures, prohibiting either life extension or children? It seems at first a decisive argument when de Grey or de Magalhaes writes that it is morally unacceptable to let old people die in order to solve problems of an overpopulated world. However, is it really obvious that extending the lives of people who already exist is always better than opting for children? Even recognising the fact that people who do not yet exist cannot suffer, a society with children might still be better than one without, for people who do exist.

Another social problem is presented as a beneficence argument in favour of accepting substantial life extension. Stephen Post argues from his expert knowledge of Alzheimer's and the pain, suffering and lack of community, self-respect and independence that go with this disease. He writes:

The stark reality of our already aging societies is that ... [m]any will experience chronic illness for which old age is the dominant risk factor, 
ranging from Alzheimer's and Parkinson's to osteoporosis and vascular disease ... The solution to this problematic of age-related disease may rest with advances in the basic science of aging that would achieve even greater prolongevity in a manner that avoids the massive debilitation that currently plagues us. (Post, 2004b: 537)

Because we might be able to prevent the strong negative value of age-related chronic diseases by anti-ageing interventions, must we develop these? They will deliver extended life expectancy, but according to Post this is a necessary price to pay for success in the fight against horrible suffering (if it is a price). Rudi Westendorp, a Dutch biomedical gerontologist, takes a similar view, but warns that effective therapies for the age-related diseases we know now will extend average life expectancy and this will unmask new diseases related to newly possible longer lives. Therapies will be needed for diseases we now know little about (Köhler, 2004) - and so on. Post's argument turns out to be not so selfevidently in favour of anti-ageing interventions. His solution is not definitive; hard choices will be needed.

Although new technological possibilities, expensive drugs and new conditions such as obesity will also be very important factors contributing to an expected rise in medical expenditure, 'an increase in life-expectancy that is not accompanied by a proportionate increase in healthy years will lead to a great increase in healthcare costs'(Knook, 2002:21). In most industrialised countries the percentage of healthcare resources ${ }^{4}$ spent on those over 65 is already much greater than the percentage spent on the entire remaining population (Beauchamp and Childress, 2001: 260). Estimates are that by 2050 the US will spend more than a thousand billion dollars annually only on Alzheimer's disease and related dementias (Olshansky et al, 2006: 31). Shall we be able to pay for an expanded scenario along these lines? Would such costs cripple all other social and personal priorities? Besides, because wealthy people live longer, schemes like the American Medicare program (309 billion dollars in 2006) might be thought to contain an ethically dubious element. To a significant extent they are equivalent to channelling tax revenue from the population at large towards expensive care for the fairly well-off (van Wijnbergen, 2002: 37). And, as the ageing populations of developed countries require more medical attention, devouring doctors and nurses from developing countries, shortages of health-care workers in the developing world would create ever more desperate situations (Garrett, 2007: 15, 26).

\section{Distributive justice}

Ethics is not only about promoting the good and preventing the bad things in life and the real possibility of shaping it yourself, it is also about the distribution of all this. Justice is about the distribution of the (lack of) things we value (such as freedom, happiness, friendship, beautiful things and good health) and the things we do not want (a life solitary, poor, nasty, brutish, and short). At the beginning 
of this chapter I distinguished between all kinds of life expectancies, but I omitted one very important factor: the 'social gradient' of longevity. Life expectancies differ according to social status. Michael Marmot's recent summary starts with an illustration from the US capital:

If you take the Metro from the southeast of downtown Washington to Montgomery County, Maryland, in the suburbs - a distance of about 14 miles - for each mile traveled life expectancy rises about a year and a half. This is the most life-enhancing journey in the world. There's a twenty-year gap between poor blacks at one end of the journey (male life expectancy fifty-seven), and rich whites at the other. (Marmot, 2005: 5)

Such inequalities in life expectancy at birth are enormous and they are universal. They exist all over the world (Mackenbach and Bakker, 2003; Marmot, 2004: 13-36). What counts as injustice depends on the theory of justice that is used. However, whether one refers to human rights (Buitenweg, 2007), ${ }^{5}$ Rawls's theory of justice as fairness (Rawls, 1999a, 1999b), Dworkin's (2000) equality of welfare and resources or Nussbaum's $(2001,2006)$ capabilities theory, differences in average life expectancy at birth of 40 years between countries (Japan and Zimbabwe), and more than 20 years for socioeconomic groups within countries - differences that can be removed and prevented by collective social action - are hard to defend as morally acceptable.

Now imagine what would happen if in such a world substantial life extension became possible through initially very expensive biotechnology like longevity pharmaceuticals or gene therapy. The demand backed by purchasing power, certainly in the beginning, would come mainly from young adults, better educated, wealthier and higher-income individuals and those with higher initial endowments of health. Socioeconomic and health inequalities would be amplified. A small group of people with an already high life expectancy would have access to life and health span extension; many less-privileged people would not. Surely this is undesirable? 'The need-based claims of the worse off to have reasonably long lives have more moral weight than the preference-based claims of the better off to have longer lives' (Glannon, 2001: 167; see also McConnel and Turner, 2005: 61; Mauron, 2005).

But the existence of social injustice can never normally be a valid reason to object morally to any improvement in the fate of human beings who do not belong to the most underprivileged ones. As Stephen Post writes:

If we were to insist that technological developments of all sorts wait until the world becomes perfectly just, there would be absolutely no scientific progress. Requiring equality as the prerequisite to biogerontological advance is to establish an obstacle that is virtually insurmountable, and so exceedingly high as to be implausible. Indeed 
this is not a requirement imposed in any other area of scientific research and development, from new dental treatments to organ transplantation ... Anti-aging research and, eventually, derived treatments, will emerge in technologically advanced countries and be affordable to those who can pay. This is the unavoidable future of all biotechnological efforts in human enhancement. And yet scientific creativity of this sort will not be inhibited. (Post, 2004b: 537; see also Harris 2003; Davis 2004)

Post is right in many ways. Demanding equality and perfect justice within and between countries as a prerequisite to the development of life extension technology is asking too much. Here, as often, 'perfection' would be the enemy of the good. On the other hand, not being able to do everything or enough, should be no excuse for doing nothing. Efforts like the UN Millennium Development Goals $^{6}$ are very significant. It is important before 2015 to try to reduce by half the proportion of people living on less than a dollar a day, to reduce by two thirds the mortality rate among children under 5 and to try to reduce by three quarters the maternal mortality ratio (Garrett, 2007:32). These are challenging goals but they are technically feasible and depend mainly on political will. In the same vein ambitious but feasible goals could be formulated to attack the shocking disparities in longevity between and also within countries. Within countries, Christine Overall proposes a qualified prolongevitism that will genuinely be for all, a kind of affirmative action in the field of life extension:

$\ldots$ as a general principle, support for increased longevity should not be limited by gender, socioeconomic class, sexual orientation, race, or ability. So the particular focus, at least in the short run, of measures to increase average life expectancy must be on members of groups that historically have been disadvantaged and that currently have low life expectancy. (Overall, 2003: 200)

This implies that increased research into conditions and diseases affecting groups of people with low life expectancy, like people of colour and poor people, is morally indicated.This kind of priority setting, including maintaining the global priority for compression of morbidity between 60 and 80 , might provoke strong political opposition, but that is no reason to be silent about a considered ethical judgement.

Furthermore, it is important to see that priorities do not have to be 'all or nothing'. Serious, strenuous attempts to tackle the national and global social gradient of longevity certainly do not require a complete halt for biogerontological research into the diseases of the oldest older people and general underlying processes of senescence. In relation to international injustice, one should not forget that numbers of the old and oldest older people in developing countries will also increase rapidly. Already the remaining life expectancy of a woman who has managed to reach the age of 60 in Brazil ( 21 more years), India (18 years) 
and Nigeria (17 years) is not so different from the number of years an average 60 -year-old female inhabitant of the US can expect to add to her life (24 years). The WHO anticipates that the percentage of people above 60 living in developing countries between now and 2050 will rise from 60 to $85 \%$ of the total global number (Kalache et al, 2005: 36; see also Kirkwood, 1999: 8; Aboderin, 2006). In China and India older people will outnumber the total current population of the US by mid-century (Olshansky et al, 2006: 31).

\section{Meanings of life ${ }^{7}$}

So far we have seen that autonomy, beneficence and justice evoke important considerations in connection with life extension. Our task seems to be to weigh pros and cons in a situation of risk and uncertainty about the future. However, some important authors attempt a more definitive position, not wishing to wait and see. They take a principled stand against life extension now. Hans Jonas, Leon Kass, Francis Fukuyama, Daniel Callahan and Bill McKibben represent what one might call a natural-law position. Not only is this a significant stance in itself, its discussion points very clearly to the way in which issues of meaning recur in the discussion of life extension.

Important aspects of the natural-law position are: that ageing is the final stage in a natural life cycle that should be cultivated (Callahan, 1995a, 1995b; see also Overall, 2003, 2004), that ageing is a natural process to be accepted and not a disease to be defeated (Callahan, 1995a, 1995b; see also Izaks and Westendorp, 2003; Caplan, 2004, 2005; Moody et al, 2004; Scully, 2004; Derkx, 2006), that the goals of medicine and health care include therapy (treatment) and prevention but not enhancement (see also Juengst, 1997,1998, 2004;Brock, 1998; Frankford, 1998), and that it is unnatural and selfish to prefer a society with many very old people and very few children over a society with fewer older people and a more natural succession of 'fresh' generations (McKibben in Stock et al, 2003; Kass, 2004: 317-18).

It seems simple to dismiss natural-law positions as an untenable deontological stance by observing that if substantial life extension starts to occur in nature it begins to be 'natural', or emphasising that humans have always changed nature (including their own natural features) in the course of civilization. Much the same goes for the religious versions of these arguments, referring to a God who has established the natural law. That humans should respect the will of God or that they should not attempt to play God encounters similar intellectual difficulties as the exhortation to respect nature, and additional difficulties too. Referring to the will of God is not a very strong argument in a pluralistic democratic society that includes atheists and agnostics.

However, it is possible to discover something important behind these arguments from nature or God, even if one rejects their absolute verbal form and is more inclined towards consequentialist ethics. Human nature is not blank, nor completely and always easily malleable. It results from millions of years of natural selection. As 
evolutionary products human beings are very complex organisms involving many trade-offs, referring back to environments in the past. We cannot design humans from scratch. Stressing that we ought to be wary of bad unintended consequences is not to claim that nothing should be changed. It is possible for a society to opt for a policy of less than one child per family to counteract undesirable effects of population growth due to increasing old-age survival, but will its individual citizens accept this policy and live up to it? Human nature is very flexible, but it is possible to ask too much of human beings. It seems relevant, for example, to speculate about the emotional implications of a population scenario with nine billion people in 2300 with an average life expectancy at birth of about 100 years and a high proportion of very old people (Basu, 2004: 93). And we should be talking here not only about what is possible for human beings, individually and as a group, but also about what is good for them and what makes their lives meaningful. To ask what desires and emotions are humanly 'natural' can be translated into a question about what desires and emotions are good and proper for human beings to have and that deserve the opportunity to be acted upon.

Authors criticising substantial life extension often point to loss of meaning. Thus, Hans Jonas writes: 'Perhaps a non-negotiable limit to our expected time is necessary for each of us as the incentive to number our days and make them count' (quoted in Post, 2004b: 536). Bill McKibben writes:

Maybe with these tools [such as germline genetic engineering] we will in some way learn to live forever, but the joy of it, the meaning of it, will melt away like ice cream on an August afternoon ... [L]ife far beyond the parameters of what we know now, life that goes beyond the normal human expectations, may be very much like a trap, and the name of that trap is a very American one - the constant idea that more is better. If it is good to live 80 years, it must be better to live 180 years and far better yet to live 300 years. (Stock et al, 2003: 7)

Yet much can be said in response to these objections to substantial life extension. What does 'making our days count' mean exactly? Horrobin $(2005: 14)$ notes that it seems odd to assert that people enjoy playing football today and experience no ennui in doing so only because they are aware that they cannot do it three centuries hence. Moreover, what are 'normal human expectations'? The normal expectations of young Western European female office workers in 2007 are very different from those of their counterparts in 1875. And is it natural or unnatural for human beings to think that more is better?

Perhaps the most fundamental criticism of the natural law position is expressed by Christine Overall (2004; see also 2003). She states that we should not argue against increasing human longevity by reference to the limited parameters set by current life expectancies. According to her, this commits the fallacy of begging the question. When contexts change and life expectancies become much longer, our judgement of life's possibilities and meanings will also change. Not only will 
childhood and age be redefined, but concepts like schooling, education, marriage, partnership, friendship, sexuality, gender, father, mother, parent, grandparent, family, work, job, career, retirement, nationality and citizenship will also acquire other meanings. Together these changes will constitute new moral systems. But I think Overall exaggerates. The way we think about human fulfilment now must be relevant to forming well-considered present-day judgements on prolongation of life. I would agree with her only if she argued that we ought not to evaluate substantial life extension exclusively by reference to the kind of life that we know now. Certainly, a comprehensive ethical judgement about future possibilities requires not just norms, values, facts and extrapolations but also moral imagination.

A concern with meaning is not the prerogative of natural-law critics of substantial life extension. Paul van Tongeren does not accept Callahan's arguments in favour of accepting a natural life cycle and a natural lifespan, but he emphasises the importance of knowing what the meaning of life is. 'If we ask to what extent we are allowed to, or even should, extend life, we have to realize that we can hardly answer that question as long as we do not know what life is all about' (van Tongeren, 1995: 36). Whether we think substantial life extension morally acceptable or desirable very much depends on what we think gives life its meaning. Here Walter Glannon advances an argument from personal identity:

Would a significantly long span of time between earlier and later mental states weaken the relations between them and make them so different that they effectively belonged to two distinct persons? ... Psychological connectedness is necessary for what matters to us. (Glannon, 2001: 160; for counterarguments see Harris, 2003: 82-5)

More discussion about meanings of life is needed. But in individualistic secular societies people have many different ideas about meanings of life, so it will be difficult to reach consensus or even mutual understanding about the value of life extension. Part of the difficulty is that in modern western societies it is widely considered that meanings of life are a private matter, not appropriate subjects of public debate.

The variety in ideas about meanings of life will be hard to handle in a democracy, because differences can be wide and not matters of degree. Transhumanists like Max More (2004), Ray Kurzweil and Terry Grossmann (2004), Nick Bostrom (2003, 2005), James Hughes (2004), Gregory Stock (2002) and Aubrey de Grey $(2003,2005)$ feel that we should not accept biological ageing as inevitable. They argue that the fundamental biology of human beings should be changed in order to root out senescence and most of death. Other thinkers, not only of the natural-law variety, see this as a dangerous illusion, holding that the propagation and cultivation of ideas like this are fundamentally detrimental to the meanings of human lives. This difference in world view is an extremely important aspect 
of the debate on substantial extension of human life expectancy. What is involved is expressed very clearly in the words of Michael Lerner:

[We] need to do the spiritual work as we grow older to accept the inevitability of death rather than acting as though aging and death could be avoided if only we had a better technology. The enormous emotional, spiritual, and financial cost of trying to hang on to life as long as possible (and to look as though we were not aging) is fostered by a marketplace that tries to sell us endless youth. It is also fostered by our cultural failure to honor our elders, provide them with real opportunities to share their wisdom, and combat the pervasive ageism with its willingness to discard people long before their creative juices have dried up, to stigmatize the sexuality of the elderly ... and to provide little in the way of adequately funded and beautifully conceived long-term care facilities. (Lerner, 2006: 308-9; see also Baars, 2006)

\section{The necessity of a humanistic gerontology and an important problem}

The preceding pages on substantial life extension started from the presupposition that biogerontology offers many unprecedented promises, but I hope that they also made clear that an exclusively biological gerontology would create problems while it tried to solve others. A technological fix for existential problems will not work and might make matters worse. Like all other fields of crucial human concern, ageing must be studied in an interdisciplinary mood and mode. 'Ageing' can be studied from different perspectives and acquires different meanings in the process: (1) ageing in the sense of (increasing numbers of persons with) increasing chronological age with all its legal and social implications, (2) ageing in the sense of biological decline and senescence, which need not keep pace with chronological age, and (3) ageing in the sense of continuously interpreting the meanings of unique and vulnerable human lives as they unfold and are experienced in time (Baars, 2006). These different concepts of ageing are often intermingled and mixed up, with chaotic and sometimes dehumanising results. A study of ageing that is culturally dominated by the second concept of ageing and by the science of biological senescence might turn out to be cruel. Biogerontologal research needs to be embedded in a democratic dialogue on meanings, goals and values.

In such a dialogue all citizens should be involved. It should not be fostered by the natural sciences alone, but also by the social sciences and humanities. None of these can be practised without recourse to explicit or implied normative assumptions and human values. Most biogerontologists I know personally would immediately assent to this: they are humanistic scientists (and often know more of philosophy and sociology than humanities scholars know of the natural sciences), but the cultural status and prominence of much-publicised biogerontological progress often has an unintended and undesirable cultural impact: 
There is an irredeemable cultural logic - if death is a solvable problem, then old age will be a failure ... Locating the meaning of death in biochemical processes and striving for ever-longer lifespans denies the possibility of old age as a valued final part of the life course. (Vincent, 2006: 694)

Research on meanings of life, the value of old age and a just and humane society requires approaches and methods fitting the subject of investigation, and in this area research confining itself to a 'hard' laboratory approach is often inappropriate. An interdisciplinary humanistic gerontology, however, is a challenging task, with risks and dangers on all sides.

One important problem can be illustrated by a passage from Clifford Geertz on the religious perspective on suffering:

... the problem of suffering is paradoxically, not how to avoid suffering but how to suffer, how to make of physical pain, personal loss, worldly defeat, or the helpless contemplation of others' agony something bearable, supportable - something, as we say, sufferable. (Geertz, quoted in Cole, 2002: 37)

Suffering is and will be a part of human existence. But human suffering always has a social, cultural and historical context, which can change. These changes matter very much and transform the character of the moral and existential issues we have to deal with. For example: my mother's parents, Roman Catholics living in the Netherlands, had five young children in 1918-19. Between December 1918 and January 1920 four of them died of whooping cough, a contagious disease now preventable by vaccination. The little card commemorating these infants' short lives starts with the exhortation 'Parents, do not weep!' and ends with the lines 'Repeat now and for ever: what God does, is done well'. Indeed, one important aspect of religious and non-religious world views is that they offer ways to accept, endure and embrace human life as it is. But a dangerous trap for religious as well as non-religious meaning frames and related ethics is that they may become too conservative, trying to fixate and immobilise cultures and societies. The dynamics of biotechnology poses many challenges here. The task for humanists is to find a wise balance between accepting humanity as it is and aiming for an enhanced humanity that could be. Humanity never just is; inevitably it must be interpreted in a changing context.

\section{Notes}

${ }^{1}$ Women have a higher risk for Alzheimer's than men, age for age, and women reach higher ages: by age 85 women outnumber men two to one, although starting out life in approximately equal numbers. Moreover, Alzheimer's does not just affect women in greater numbers because they are more likely to get it.They 


\section{Valuing older people}

are also more likely to end up taking care of someone who has it, like a spouse, a parent, or a sibling (Legato, 2005: 212-13).

${ }^{2}$ Bernice Neugarten has in 1978 already pointed out that the evidence is scanty that 'it will be possible to stretch out the active part of life without increasing the period of physical disability’ (Neugarten, 1996: 343).

${ }^{3}$ The seven categories of damage are: (1) cell death without matching replacement (especially important in the heart and the brain),(2) unwanted cells, eg visceral fat and senescent cells (important in arthrosis and diabetes), (3) nuclear (epi)mutations causing cancer, (4) mitochondrial mutations, (5) extracellular protein/protein cross-links (eg leading to high blood pressure), (6) extracellular aggregates (eg resulting in amyloid involved in Alzheimer's disease), and (7) intracellular aggregates (eg resulting in hardening of the arteries).

${ }^{4}$ I should note that it has not become clear to me what exactly is counted as 'health-care resources'.

${ }^{5}$ See also www1.umn.edu/humanrts/index.html

${ }^{6}$ www.un.org/millenniumgoals/\#

${ }^{7}$ Autonomy, beneficence and justice are also very relevant for the experience of a meaningful life (see Baumeister, 1991). In this section on meaning of life I specifically refer to human needs for purpose, fulfilment and feeling one with or part of a valuable whole.

\section{Acknowledgments}

Research for this paper was supported by a grant (code: 050-32-570) from NWO (Netherlands Organisation for Scientific Research).

I should also like to thank Jan Baars, Adri Smaling, Hugo Letiche, Janneke van Mens-Verhulst (University for Humanistics, Utrecht), Dick Knook and Diana van Heemst (Leiden University Medical Center), Pearl Dykstra (Netherlands Interdisciplinary Demographic Institute, The Hague) and my colleagues in the research project 'Towards a lingua democratica for the public debate on genomics', especially Cor van der Weele and Harry Kunneman, for helpful remarks on this topic. 


\section{References}

Aboderin, I. (2006) 'Ageing in Africa', in Wellcome Focus 2006: Ageing: Can we stop the clock, London: The Wellcome Trust.

Arking, R. (2004) 'Extending human longevity: a biological probability', in S.G. Post and R.H. Binstock (eds) The fountain of youth: Cultural, scientific, and ethical perspectives on a biomedical goal, Oxford: Oxford University Press, pp 177-200.

Austad, S.N. (1997) Why we age:What science is discovering about the body's journey through life, New York: John Wiley.

Baars, J. (2006) Het nieuwe ouder worden: paradoxen en perspectieven van leven in de tijd, Amsterdam: SWP, Humanistics University Press.

Baltes, P.B. (2003) 'Extending longevity: dignity gain - or dignity drain?', MaxPlanckResearch, vol 2003, no 3, pp 14-19.

Basu,A.M. (2004) 'Towards an understanding of the emotions in the population of 2300 ', in Department of Economic and Social Affairs United Nations, Population Division (ed) World population to 2030, New York: United Nations, pp 89-98.

Baumeister, R.F. (1991) Meanings of life, New York: Guilford Press.

Beauchamp, T.L. and Childress, J.F. (2001) Principles of biomedical ethics (5th edn), Oxford: Oxford University Press.

Benhabib, S. (ed) (1996) Democracy and difference: Contesting the boundaries of the political, Princeton, NJ: Princeton University Press.

Borgerhoff Mulder, M. (1998) 'The demographic transition: are we any closer to an evolutionary explanation?' Tree, vol 13, no 7, pp 266-70.

Bostrom, N. (2003) 'Human genetic enhancements: a transhumanist perspective', Journal of Value Inquiry, vol 37, no 4, pp 493-506.

Bostrom, N. (2005) 'Transhumanist values', in F. Adams (ed) Ethical issues for the 21st century, Charlottesville,VA: Philosophical Documentation Center (no page numbers available).

Brandt, R.B. (1959) Ethical theory: The problems of normative and critical ethics, Englewood Cliffs, NJ: Prentice-Hall.

Brock, D.W. (1998) 'Enhancements of human function: some distinctions for policymakers', in E.Parens (ed) Enhancing human traits: Ethical and social implications, Washington, DC: Georgetown University Press, pp 48-69.

Buitenweg, R. (2007) Human rights, human plights in a global village, Atlanta, GA: Clarity Press.

Callahan, D. (1995a) 'Aging and the life cycle: a moral norm?', in D. Callahan, R.H.J. ter Meulen and E. Topinková (eds) $A$ world growing old:The coming health care challenges, Washington DC: Georgetown University Press,pp 20-7.

Callahan, D. (1995b) Setting limits: Medical goals in an aging society (expanded edn), Washington, DC: Georgetown University Press.

Caplan,A.L. (2004) 'An unnatural process: why it is not inherently wrong to seek a cure for aging', in S.G. Post and R.H. Binstock (eds) The fountain of youth: Cultural, scientific, and ethical perspectives on a biomedical goal, Oxford: Oxford University Press, pp 271-85. 
Caplan,A.L. (2005) 'Death as an unnatural process: why is it wrong to seek a cure for ageing?', EMBO Reports, vol 6, July, pp 72-5.

Carens, J.H. (2000) Culture, citizenship, and community: A contextual exploration of justice as evenhandedness, Oxford: Oxford University Press.

Cole, T.R. (2002) 'On the possibilities of spirituality and religious humanism in gerontology or reflections of one aging American cultural historian', in L. Andersson (ed) Cultural gerontology, Westport, CT: Auburn House, pp 25-44.

Davis, J.K. (2004) 'Collective suttee: is it unjust to develop life extension if it will not be possible to provide it to everyone?', in A.D.N.J. de Grey (ed) Strategies for engineered negligible senescence: Why genuine control of aging may be foreseeable, New York: New York Academy of Sciences, pp 535-41.

de Grey, Aubrey D.N.J. (2003) 'The foreseeability of real anti-aging medicine: focusing the debate', Experimental Gerontology, vol 38, no 9, pp 927-34.

de Grey, Aubrey D.N.J. (2005) 'Foreseeable and more distant rejuvenation therapies', in S.I.S. Rattan (ed) Aging interventions and therapies, Singapore:World Scientific Publishing, pp 379-95.

de Grey, A.D.N.J., Ames, B.N., Andersen, J.K., Bartke, A., Campisi, J., Heward, C.B., McCarter, R.J.M. and Stock, G. (2002) 'Time to talk SENS: critiquing the immutability of human aging', in D. Harman (ed) Increasing healthy life span: Conventional measures and slowing the innate aging process, New York: New York Academy of Sciences, pp 452-62.

Derkx, P. (2006) 'Ouder worden: te aanvaarden natuurlijk proces of te bestrijden ziekte?', Tijdschrift voor Humanistiek - Journal for Humanistics, vol 7, no 28, pp 82-90.

Dworkin, R. (2000) Sovereign virtue: The theory and practice of equality, Cambridge, MA: Harvard University Press.

Dykstra, P.A. (2002) 'Ageing in the Netherlands in a macro and micro perspective', in R. de Bok (ed) Ageing in Europe:The social demographic and financial consequences of Europe's ageing population, Breda: PlantijnCasparie, pp 6-17.

Estep, P.W.III, Kaeberlein, M., Kapahi, P., Kennedy, B.K., Lithgow, G.J., Martin, G.M., Melov, S., Powers, R.W. and Tissenbaum, H.A. (2006) Life extension pseudoscience and the SENS plan, Technology Review (MIT), www. technologyreview.com/sens/index.aspx

Frankford, D.M. (1998) 'The treatment/enhancement distinction as an armament in the policy wars', in E. Parens (ed) Enhancing human traits: Ethical and social implications, Washington, DC: Georgetown University Press, pp 70-94.

Fries, J.F. (1980) 'Aging, natural death, and the compression of morbidity', The New England Journal of Medicine, vol 303, 17 July, pp 130-5.

Garrett, L. (2007) 'The challenge of global health', Foreign Affairs, vol 86, no 1, pp 14-38.

Glannon, W. (2001) Genes and future people: Philosophical issues in human genetics. Boulder, CO:Westview Press.

Habermas, J. (1998) Between facts and norms: Contributions to a discourse theory of law and democracy, Cambridge, MA: MIT Press. 
Harris,J. (2003) 'Intimations of immortality: the ethics and justice of life extending therapies', in M.D.A. Freeman (ed) Current legal problems 2002, Oxford: Oxford University Press, pp 65-95.

Hayflick, L. (1994) How and why we age, New York: Ballantine Books.

Holliday, R. (1995) Understanding ageing, Cambridge: Cambridge University Press.

Holliday, R. (2006) 'Aging is no longer an unsolved problem in biology', in S.I.S. Rattan, P. Kristensen and B.F.C. Clark (eds) Understanding and modulating aging, Boston, MA: Blackwell, pp 1-9.

Holm, S. (2004) 'I want to live forever - a review of [Christine Overall's] Aging, death and human longevity: A philosophical inquiry', Medicine, Health Care and Philosophy, vol 7, no 1, pp 105-07.

Horrobin, S. (2005) 'The ethics of aging intervention and life-extension', in S.I.S. Rattan (ed) Aging interventions and therapies, Singapore: World Scientific Publishing, pp 1-27.

Horrobin, S. (2006) 'The value of life and the value of life extension', in S.I.S. Rattan, P. Kristensen and B.F.C. Clark (eds) Understanding and modulating aging, Boston, MA: Blackwell, pp 94-105.

Hrdy, S.B. (1999) Mother nature: A history of mothers, infants, and natural selection, New York: Random House (Pantheon Books).

Hughes,J. (2004) Citizen cyborg:Why democratic societies must respond to the redesigned human of the future, Boulder, CO: Westview Press.

Izaks, G.J. and Westendorp, R.G.J. (2003) 'Ill or just old? Towards a conceptual framework of the relation between ageing and disease', BMC Geriatrics, vol 3, no 7 (no page numbers available).

Juengst,E.T. (1997) 'Can enhancement be distinguished from prevention in genetic medicine?', The Journal of Medicine and Philosophy, vol 22, no 2, pp 125-42.

Juengst, E.T. (1998) 'What does enhancement mean?', in E. Parens (ed) Enhancing human traits: Ethical and social implications, Washington, DC: Georgetown University Press, pp 29-47.

Juengst, E.T. (2004) 'Anti-aging research and the limits of medicine', in S.G. Post and R.H. Binstock (eds) The fountain of youth: Cultural, scientific, and ethical perspectives on a biomedical goal, Oxford: Oxford University Press, pp 321-39.

Juengst, E.T., Binstock, R.H., Melhman, M., Post, S.G. and Whitehouse, P. (2003) 'Biogerontology, "anti-aging medicine", and the challenge of human enhancement', Hastings Center Report, vol 33, no 4, pp 21-30.

Kalache, A., Aboderin, I. and Hoskins, I. (2002) 'Compression of morbidity and active ageing: key priorities for public health policy in the 21st century', Bulletin of the World Health Organization, vol 80, no 3, pp 243-44.

Kalache, A., Barreto, S.M. and Keller, I. (2005) 'Global ageing: the demographic revolution in all cultures and societies', in M.L. Johnson, V.L. Bengtson, P.G. Coleman and T.B.L. Kirkwood (eds) The Cambridge handbook of age and ageing, Cambridge: Cambridge University Press, pp 30-46. 
Kass, L.R. (2004) 'L'chaim and its limits: why not immortality?', in S.G. Post and R.H.Binstock (eds) The fountain of youth: Cultural, scientific, and ethical perspectives on a biomedical goal, Oxford: Oxford University Press, pp 304-20.

Kirkwood, T.B.L. (1999) Time of our lives: The science of human aging, Oxford: Oxford University Press.

Kirkwood,T.B.L. (2005) 'Understanding the odd science of aging', Cell, vol 120, pp 437-47.

Knook, D.L. (2002) 'Europe's ageing population and consequences for health care', in R. de Bok (ed) Ageing in Europe:The social, demographic and financial consequences of Europe's ageing population, Breda: PlantijnCasparie, pp18-26.

Köhler, W. (2004) “"Ouderdom is groeiende chaos”, interview met Rudi Westendorp', M: het maandblad van NRC Handelsblad, August, pp 34-9.

Korten, D.C. (2000) The post-corporate world: Life after capitalism, West Hartford, CT/San Francisco, CA: Kumarian Press/Berrett-Koehler Publishers.

Kurzweil, R. and Grossmann, T. (2004) Fantastic voyage: Live long enough to live forever, Emmaus, PA: Rodale.

Legato, M.J. (2005) Why men never remember and women never forget, Emmaus, PA: Rodale, pp 199-221.

Lerner, M. (2006) The left hand of God: Taking back our country from the religious Right, New York: HarperCollins, HarperSanFrancisco.

Mackenbach, J.P. and Bakker, M.J. (2003) 'Tackling socioeconomic inequalities in health: analysis of European experiences', The Lancet, vol 362, 25 October, pp 1409-14.

Marmot, M. (2004) The status syndrome: How social standing affects our health and longevity, New York: Henry Holt, Times Books.

Marmot, M. (2005) Social determinants of longevity and mortality, SAGE Crossroads, 28 June, www.SageCrossroads.net

Marres, N.S. (2005) 'No issue, no public: democratic deficits after the displacement of politics', Universiteit van Amsterdam, http://dare.uva.nl/document/17061

Mauron, A. (2005) 'The choosy reaper: from the myth of eternal youth to the reality of unequal death', EMBO Reports, vol 6, July, pp 67-71.

McConnel, C. and Turner, L. (2005) 'Medicine, ageing, and human longevity: the economics and ethics of anti-ageing interventions', EMBO Reports, vol 6, July, pp 59-62.

Miller, R.A. (2004) 'Extending life: scientific prospects and political obstacles', in S.G. Post and R.H. Binstock (eds) The fountain of youth: Cultural, scientific, and ethical perspectives on a biomedical goal, Oxford: Oxford University Press, pp 228-48.

Moody, H.R. (1995) 'The meaning of old age: scenarios for the future', in D. Callahan, R.H.J. ter Meulen, and E.Topinková (eds) A world growing old:The coming health care challenges, Washington DC: Georgetown University Press, pp 9-19.

Moody, H.R., Caplan, A. and Kondracke, M. (2004) Is aging a disease?, SAGE Crossroads, 22 January, www.SageCrossroads.net 
More, M. (2004) 'Superlongevity without overpopulation', in Immortality Institute and S. Sethe (eds) The scientific conquest of death: Essays on infinite lifespans, Buenos Aires: LibrosEnRed, pp 169-85.

Mykytyn, C.E. (2006) 'Contentious terminology and complicated cartography of anti-aging medicine', Biogerontology, vol 7, no 4,pp 279-85.

Neugarten, B.L. (1996) 'Social implications of life extension [1978]', in D.A. Neugarten (ed) The meanings of age: Selected papers of Bernice L. Neugarten, Chicago: The University of Chicago Press, pp 339-45.

Nussbaum, M.C. (2001) Women and human development: The capabilities approach, Cambridge: Cambridge University Press.

Nussbaum, M.C. (2006) Frontiers of justice: Disability, nationality, species membership, Cambridge, MA: Harvard University Press, Belknap Press.

Olshansky, S.J., Perry, D., Miller, R.A. and Butler, R.N. (2006) 'In pursuit of the longevity dividend: what should we be doing to prepare for the unprecedented aging of humanity?', The Scientist, vol 20, no 3, pp 28-36.

Overall, C. (2003) Aging, death, and human longevity: A philosophical inquiry, Berkeley, CA: University of California Press.

Overall, C. (2004) 'Longevity, identity, and moral character: a feminist approach', in S.G. Post and R.H. Binstock (eds) The fountain of youth: Cultural, scientific, and ethical perspectives on a biomedical goal, Oxford: Oxford University Press, pp 286-303.

Post, S.G. (2004a) 'Decelerated aging: should I drink from a fountain of youth?', in S.G. Post and R.H. Binstock (eds) The fountain of youth: Cultural, scientific, and ethical perspectives on a biomedical goal, Oxford: Oxford University Press, pp 72-93.

Post, S.G. (2004b) 'Establishing an appropriate ethical framework: the moral conversation around the goal of prolongevity', Journal of Gerontology: Biological Sciences, vol 59, no 6, pp 534-9.

President's Council on Bioethics (2003) Beyond therapy: biotechnology and the pursuit of happiness, New York: HarperCollins, Regan Books.

Rawls,J. (1999a) The law of peoples, with 'the idea of public reason revisited', Cambridge, MA: Harvard University Press.

Rawls,J. (1999b) A theory of justice: Revised edition, Cambridge, MA:Belknap Press of Harvard University Press.

Scully, J.L. (2004) 'What is a disease? Disease, disability and their definitions', EMBO Reports, vol 5, no 7, pp 650-3.

Stock, G. (2002) Redesigning humans: Our inevitable genetic future, Boston, MA: Houghton Mifflin.

Stock, G., McKibben, B. and Kondracke, M. (2003) Do we want science to reinvent human aging?, SAGE Crossroads, 27 March, www.SageCrossroads.net

Turner, L. (2004) 'Life extension research: health, illness, and death', Health Care Analysis, vol 12, no 2, pp 117-29. 
van Tongeren, P. (1995) 'Life extension and the meaning of life', in D. Callahan, R.H.J. ter Meulen and E. Topinková (eds) A world growing old:The coming health care challenges, Washington, DC: Georgetown University Press, pp 28-38.

van Wijnbergen, S.J.G. (2002) 'Economic aspects of an ageing population', in R. de Bok (ed) Ageing in Europe: The social, demographic and financial consequences of Europe's ageing population, Breda: PlantijnCasparie, pp 28-39.

Vincent, J.A. (2006) 'Ageing contested: anti-ageing science and the cultural construction of old age', Sociology, vol 40, no 4, pp 681-98.

Warner, H. et al (2005) 'Science fact and the SENS agenda: what can we reasonably expect from ageing research', EMBO Reports, vol 6, no 11,pp 1006-8. 
VALUING OLDER PEOPLE

A humanist approach to ageing

Edited by Ricca Edmondson and Hans-Joachim von Kondratowitz 
This edition published in Great Britain in 2009 by

The Policy Press

University of Bristol

Fourth Floor

Beacon House

Queen's Road

Bristol BS8 1QU

UK

Tel +44(0)1173314054

Fax +44(0)1173314093

e-mail tpp-info@bristol.ac.uk

www.policypress.org.uk

North American office:

The Policy Press

c/o International Specialized Books Services (ISBS)

920 NE 58th Avenue, Suitc 300

Portland, OR 97213-3786, USA

Tel +1 5032873093

Fax +1 5032808832

e-mail info@isbs.com

(C) The Policy Press 2009

British Library Cataloguing in Publication Data

A catalogue record for this book is available from the British Library.

Library of Congress Cataloging-in-Publication I)ata

A catalog record for this book has been recuested.

ISBN 9781847422910 paperback

ISBN 9781847422927 hardcover

The right of Ricca Edmondson and Hans-Joachim von Kondratowitz to be identified as editors of this work has been asserted by them in accordance with the 1988 Copyright, Designs and Patents Act.

All rights reserved: no part of this publication may be reproduced, stored in a retrieval system, or transmitted in any form or by any means, electronic, mechanical, photocopying, recording, or otherwise without the prior permission of The Policy Press.

The statements and opinions contained within this publication are solely those of the editors and contributors and not of the University of Bristol or The Policy Press. The University of Bristol and The Policy Press disclaim responsibility for any injury to persons or property resulting from any material published in this publication.

The Policy Press works to counter discrimination on grounds of gender, race, disability, age and sexuality.

Cover design by The Policy Press

Printed and bound in Great Britain by TJ International Ltd, Padstow. 


\section{Contents}

List of tables and figures

Notes on contributors

Acknowledgements

Foreword

Judith Phillips

Introduction

Ricca Edmondson and Hans-Joachim von Kondratowitz

Part One: Religion, spirituality, cultural resources and creating meaning one Religious belonging and spiritual questioning: a Western European perspective on ageing and religion Peter G. Coleman

two Spirituality: a means for achieving integration in personal and community spheres in an ageing Singapore Kalyani K. Mehta

three Integrating the sacred in creative ageing Michele Dillon

four Atheist convictions, Christian beliefs or 'keeping things open'?

Patterns of world views among three generations in East German families Monika Wohlrab-Sahr

five Beyond dialogue: entering the fourth space in old age Haim Hazan

\section{Part Two: Norms, values and gerontology}

six The long road to a moralisation of old age Hans-Joachim von Kondratowitz

seven How to balance generations: solidarity dilemmas in a European perspective Svein Olav Daatland

eight Pension systems and the challenge of population ageing: what does the public think? Dina Frommert, Dirk Hofäcker, Thorsten Heien and Hans-jürgen Andreß

nine Ethos of care and environment in long-stay care settings: impacts on residents' lives Adeline Cooney and Kathy Murphy

ten Engineering substantially prolonged human lifespans: biotechnological enhancement and ethics Peter Derkx 
Valuing older people

Part Three:Ageing and wisdom? Conflicts and contested developments

eleven Wisdom: a humanist approach to valuing older people

Ricca Edmondson

twelve Social practices, moral frameworks and religious values in the lives of older people

Carmel Gallagher

thirteen 'Woo-hoo, what a ride!' Older people, life stories and active ageing

Lorna Warren and Amanda Clarke

fourteen Does eldership mean anything in the contemporary West?

James Nichol

fifteen Talk about old age, health and morality

Outi Jolanki

\section{Afterwords}

sixteen Exploring positive images of ageing: the production of calendars

Eileen Fairhurst and Sue Baines

seventeen Gateways to humanistic gerontology

Ronald J. Manheimer

Index 